TAPROBANICA, ISSN 1800-427X. October, 2011. Vol. 03, No. 02: pp. 86-92, 4 pls.

(C) Taprobanica Private Limited, Jl. Kuricang 18 Gd.9 No.47, Ciputat 15412, Tangerang, Indonesia.



\title{
TAXONOMIC STATUS AND STUDIES OF THREE HIGH ALTITUDE BUTTERFLIES Polyommatus LATREILLE, 1804 AND A NEW RECORD OF P. florenciae (TYTLER, 1926) FROM INDIA
}

\footnotetext{
${ }^{\mathbf{1}}$ High Altitude Regional Centre, Zoological Survey of India, Saproon, Solan 173211, Himachal Pradesh, India E-mail: avtarkaur2000@gmail.com

${ }^{2}$ Department of Biology, A. S. College, Khanna 141402, Punjab, India

${ }^{3}$ SUS College of Research \& Technology, Mohali 140306, Punjab, India
}

\begin{abstract}
The status of three species of high altitude butterflies, Polyommatus Latreille, 1804, from the Indian Himalayas has been assessed and the species $P$. florenciae (Tytler, 1926) has been recorded for the first time from India. Details of the genitalia for each species are illustrated and described for the first time.
\end{abstract}

Key words: Lycaenidae, Polyommatinae, genitalia, Himalayas, taxonomy, Lepidoptera

\section{Introduction}

Hemming (1967) has explained how the genus Polyommatus Latreille, 1804 was originally established based on a misidentified type-species, $P$. argus Fabricius, a name never published by Fabricius as a new species. Owing to such a misconception in the initial stages, the name Polyommatus has been used in various incorrect circumstances since the nineteenth century. Rather than going too deep into the historical account of the genus, it seems appropriate to add here that the name $P$. icarus Rottemburg, 1775 (type-species) was placed on the Official List of specific names in Zoology as Name No. 1515. While dealing with Lycaenidae diversity from the Indian subcontinent,
Evans (1932), Peile (1937) and Wynter-Blyth (1957) have made use of the generic name Polyommatus Latreille, 1804 in its broad comprehensive sense, ignoring some earlier works. Tutt (1909), Hemming (1933) and Stempffer (1937) have made use of different generic names for easily recognizable divisions of the genus Polyommatus, as per arrangement in the Natural History Museum, London. In a major revision, Cantlie (1963) divided the genus, under reference (sensu Evans, 1932 loc. cit.), into thirteen genera viz., Polyommatus, Phengaris, Philotes, Plebejus, Aricia, Turanana, Vaccinina, Agriades, Albulina, Glaucopsyche, Iolana, Cyaniris and Lycaeides 
(Eliot, 1973; Bridges, 1988; Smith, 1989). According to Varshney (1997), the taxon Polyommatus (sens. str.) is, in fact, a Palaearctic genus restricted to the Himalayan mountain range (Chitral, Hunza, Khyber, Kashmir, Ladakh, Kumaon, Sikkim) in India and neighboring countries like Nepal and Baluchistan (Pakistan). Further, due to frequent transfers of different species between allied genera, the total number of species in this genus at present remains fluid. However, about nine species viz., $P$. icarus Rottemburg, $P$. eros Ochsenheimer, $P$. florenciae Tytler, $P$. sarta Alpheranky, $P$. devanica Moore, $P$. stoliczkana Felder \& Felder, $P$. sieversi Christoff, $P$. bogra Evans and $P$. nepalensis Forster are represented in the above mentioned areas/localities and out of these, the former five are represented in the Himalayan region in India (Evans, loc. cit.; Wynter-Blyth, loc. cit.; Cantlie, loc. cit.; Smith, loc. cit.). During the course of present surveys, three species i.e., $P$. icarus, $P$. eros and $P$. florenciae were collected from various localities in the NorthWest Himalaya Mountains between altitudes ranging from $2680 \mathrm{~m}$ a.s.l. to $4050 \mathrm{~m}$ a.s.l.

Observations (scale of photos is $10 \mathrm{~mm}$ ):

Polyommatus Latreille, 1804

Common name: The Meadow Blues

Latreille, 1804, Nouveau Dictionnaire d'Histoire Naturelle, 24 (Tab): 200; Stempffer, 1937, Bulletin de la Societe entomologique de France: 296.

Polymaster Gaede, 1931, In Strand's Lepidoptera Catalogue, 46: 510.

Bryna Evns, 1912, Journal of Bombay natural History Society, 21: 284.
Type-species: Papilio icarus Rottemburg, 1775 Rottemburg, 1775, Naturforscher, 6: 31.

Generic diagnosis: Eyes and labial palpi hairy; antenna with well defined club, spatula-shaped, dorsally with a subapical patch of white scales; each leg with femur longer than tibia, the former hairy; forewing with 11 veins, vein Sc and vein R1 free, origin of the latter nearer to base than the origin of vein Culb; underside of both wings with all spots black, encircled white; hindwing tailless; male genitalia with uncus divided, each uncus lobe swollen apically, tip abruptly acute, each valvae spindle shaped; female genitalia with genital plate membranous, with a marginal strip of sclerotization and a median sclerotized area above ostium pouch.

Remarks: Besides other already known morphological characters, the male and female genitalia of three species viz., $P$. icarus, $P$. eros and $P$. florenciae have been examined in considerable detail. Examination of the genitalia was essential for validating the determination of species. Accordingly, a consolidated key to the presently studied species was prepared by taking into account various morphological characters, including genitalia. Superficially the genitalia suggest the taxa may be conspecific. However, a critical examination shows that characters such as the shape and curves of uncus lobes, vinculum and valvae of the male genitalia and the genital plate in the female genitalia serve as diagnostic characters. The same general pattern of both the male and female genitalia indicates that all the three species viz., $P$. icarus, $P$. eros and $P$. florenciae are congeneric and form a natural group of species.

\section{Key for differentiating Polyommatus: florenciae, eros, and icarus}

1 a. Undersurface of forewings always without a spot in cell; undersurface of hindwings with the basal spot only in space Sc+R1 prominent, others obscure; male genitalia with each brachium unevenly curved; female genitalia with ostium pouch lacking median sclerotization at caudal end

P. florenciae Tytler

b. Undersurface of forewings usually with a spot in cell; undersurface of hindwings with more than one equally prominent basal spot; male genitalia with each brachium evenly curved; female genitalia with ostium pouch bearing a median sclerotization at caudal end 2

2 a. Undersurface of forewings with discal spots in R5; veins M1 and M2 arranged in a straight line; male genitalia with vinculum abruptly tapering towards ventral end; lower edge of each valva curved; female genitalia with genital plate carrying an inverted U-shaped sclerotized area; ostium pouch present between the arms of this U-shaped sclerotization ....

P. eros Ochsenheimer

b. Undersurface of forewings with discal spots in R5; veins M1 and M2 arranged on a curve; male genitalia with vinculum gradually tapering towards ventral end; lower edge of each valva straight; female genitalia with genital plate carrying a W-shaped sclerotized area; ostium pouch situated beyond W-shaped sclerotized region 
Polyommatus florenciae (Tytler, 1926) (Figs. 1-3) Common name: The Silvery Meadow Blue

Tytler, 1926, Journal of Bombay Natural History Society, 31: 583 (Lycaena); Evans, 1932, Identification of Indian Butterflies (2nd ed.): 233 (Polyommatus); Cantlie, 1963, Lycaenidae portion of Butterflies (Revised): 61 (Polyommatus).

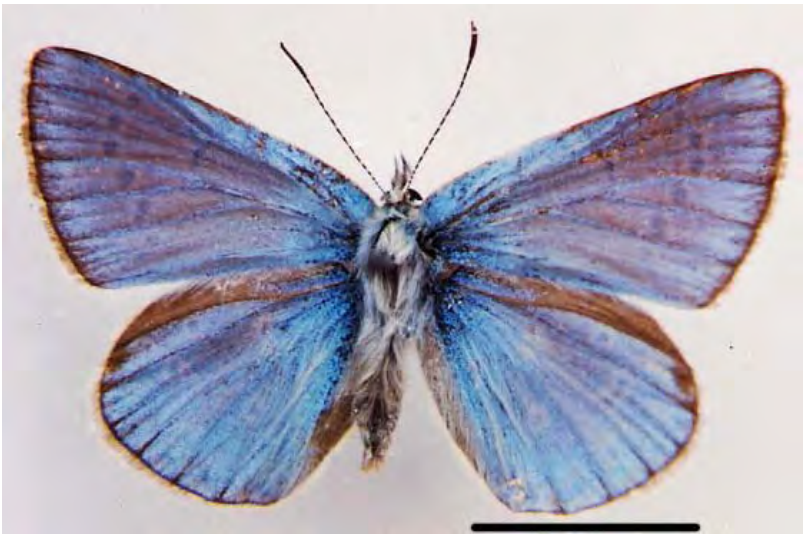

Fig. 1: Dorsal view of Polyommatus florenciae male



Fig. 2: Ventral view of Polyommatus florenciae male

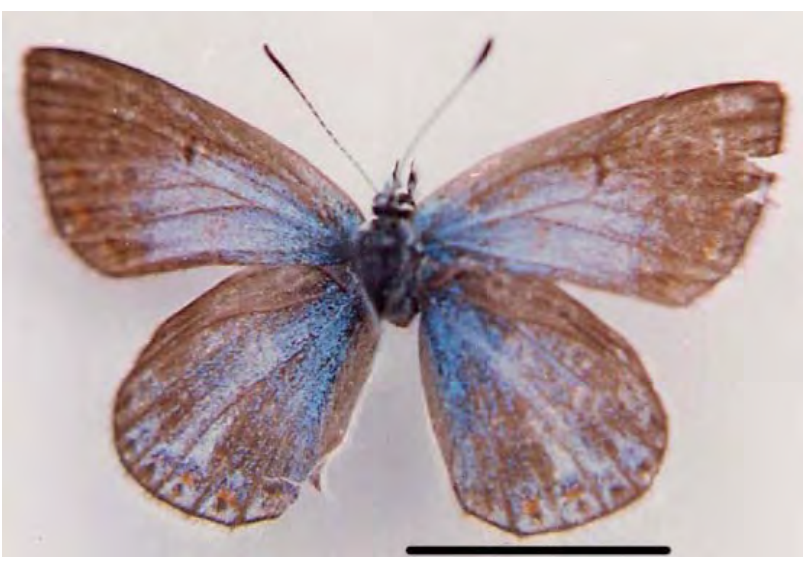

Fig. 3: Dorsal view of Polyommatus florenciae female

Venation: Forewings: discal cell almost equal to half of the wing length, veins Sc and R1 free, briefly approximating; vein R4 wanting; stalk of veins R3+R5 and vein M1 separated at their origin; vein R3 arising before middle of vein R5; vein M2 almost equidistant between vein M1 and vein M3; discocellulars incomplete; origin of vein $\mathrm{Cu}$-la well before end cell. Hindwings: discal cell less than half of wing length; vein M2 closer to vein M1 than vein M3; discocellulars thin, complete; origin of vein $\mathrm{Cu}$-la well before end of the cell.

Male Genitalia: Symmetrical, well sclerotized, large sized; uncus divided into two lobes, each lobe elongated, compressed laterally, much broader in middle, apex acute, sparsely pilose; brachia short, slender, peg-shaped, unevenly curved, tapering to sharp apices; tegumen thick band-shaped, with posterior angles produced laterally; suspensorium present; vinculum with upper portion much broader, abruptly tapering into narrow ridge-like lower portion; saccus absent; each valva large, broader in middle, with curved dorsal and ventral edges; costa very narrow; sacculus broad, elongated flap-like; ampulla well separated from harpe, thin, inwardly curved; harpe broad with squarish apex; valva pilose along margins and inner surface; juxta Ushaped, with elongated arms; aedeagus short, straight, slender, ventrally placed, subzone much longer than suprazone, the latter narrower, subzone laterally produced at entry of bulbus ejaculatorius, the latter thin and membranous, ductus ejaculatorius entering cephalad.

Female Genitalia: Lodix large, slightly arched, rectangular plate-shaped, with narrow anterior margin; genital plate comprising a W-shaped sclerotization with elongated lateral arms, otherwise membranous; ductus seminalis enters ductus bursae near base on dorsal side; ductus bursae membranous, opens exteriorly through on elongated ostium pouch, the latter lacking median sclerotization at caudal end, gradually broadens before imperceptibly entering into corpus bursae; corpuse bursae membranous, ovate, shorter than ductus bursae, signum absent; apophyses anteriores knob-shaped; apophyses posteriores narrow, moderate, curved rods; papilla analis somewhat rectangular, partly sclerotized, pilose.

Forewing length: Male, 17 mm; Female, $17 \mathrm{~mm}$.

Material examined: Himachal Pradesh: 1 male (23.VI.1995), 3 males, 2 females (21.VI.1996), Kaza - Lahaul \& Spiti (3600 m a.s.l.); 2 males, 1 female (26.VI.1995), Losar - Lahaul \& Spiti (4079 m a.s.l.); 2 males (20.VI.1996), Ki - Lahaul \& Spiti (4116 m a.s.l.); 3 males (21.VI.1996), Gulling - 
Lahaul \& Spiti (3500 m a.s.l.); 4 males, 1 female (16.VI.1996), Rakcham - Kinnaur (2900 m a.s.l.); 1 female (26.VI.1996), Puh - Kinnaur (2837 m a.s.l.); 1 male (24.VII.2009), 4 males, 3 females (25.VII.2009), Sural - Pangi (3234 m a.s.l.).

Current distribution: 2837 - 4116 m a.s.l.

Previous distribution: Baroghil Pass, Gilgit to Chitral, Hunza.

\section{Larval food plant: unknown}

Remarks: Following Cantlie (1963), Bridges (1988) and Varshney (1997), a sample consisting of twenty individuals (fifteen males and five females), has been identified as Polyommatus florenciae (Tytler, 1926). However, prior to this, Evans (1932) has erroneously treated this species as a subspecies of the species $P$. poseidon Herrich-Schäffer, 1851 which is now considered under the genus, Agrodiaetus Hübner, 1822 (Bridges, loc. cit.). While examining various individuals referable to this species, it has been observed that the number of basal spots on undersurface of the hindwings is variable. There may be two basal spots (three examples) or one (seventeen examples). Similarly, though a spot in the discal cell on the undersurface of the forewings is usually absent, such a spot has been observed in two individuals on the right side of the same insect. Accordingly, a series of four males and two females showing variations have been dissected in order to confirm their identity by examination of the genitalia. An illustrated account of the male and female genitalia is being given for the first time (Pl. 4, Fig. 11).

The present surveys observed adults of $P$. florenciae to be common in localities such as Sural, Rakcham, Gulling, Losar, Kaza, Ki and Puh (Himachal Pradesh) in the North-West Himalaya, from where it is being reported for the first time from India. However, this species has been considered to be rare (Evans, 1932; Cantlie, 1963) or endangered (Varshney, 1997).

Polyommatus eros (Ochsenheimer, 1807) (Figs. 4-7) Common name: The Common Meadow Blue Ochsenheimer, 1807, Schmetterlinge Europa 1 (2): 42 (Papilio); Bingham, 1907, Fauna of British India, Butterflies II: 340 (Lycaena); Evans, 1932, Identification of Indian Butterflies ( $2^{\text {nd }}$ edition): 231 (Polyommatus). Lycaena amor Staudinger, 1886, Stettiner Entologische Zeitung, 47: 211. Lycaena amorata Alpheraky, 1897, In Romanoff Memoires Lepidoptera, 9: 113.

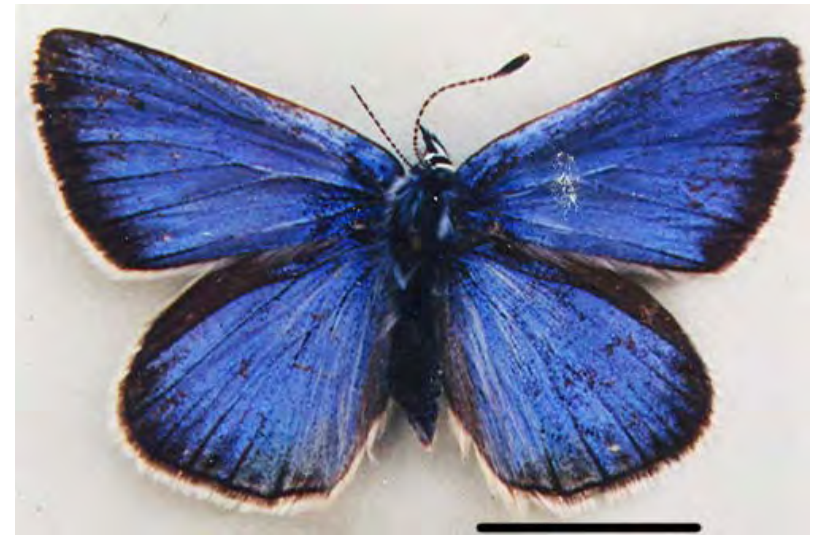

Fig. 4: Dorsal view of Polyommatus eros male

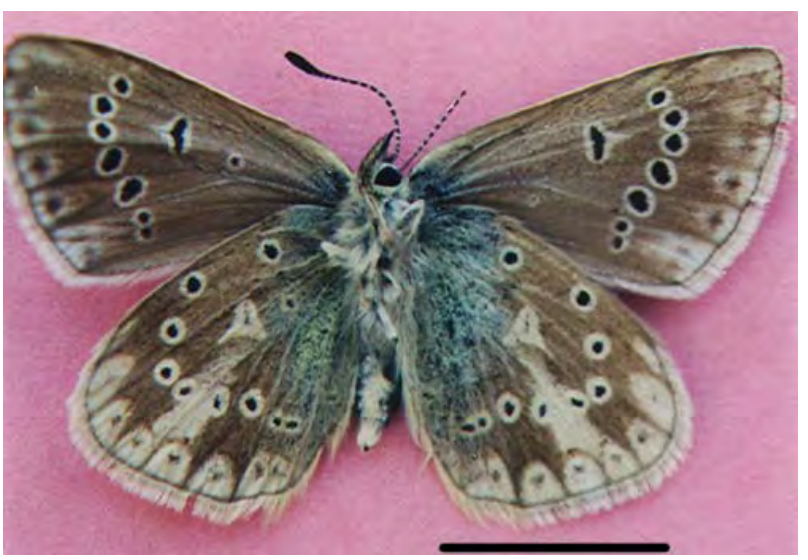

Fig. 5: Ventral view of Polyommatus eros male

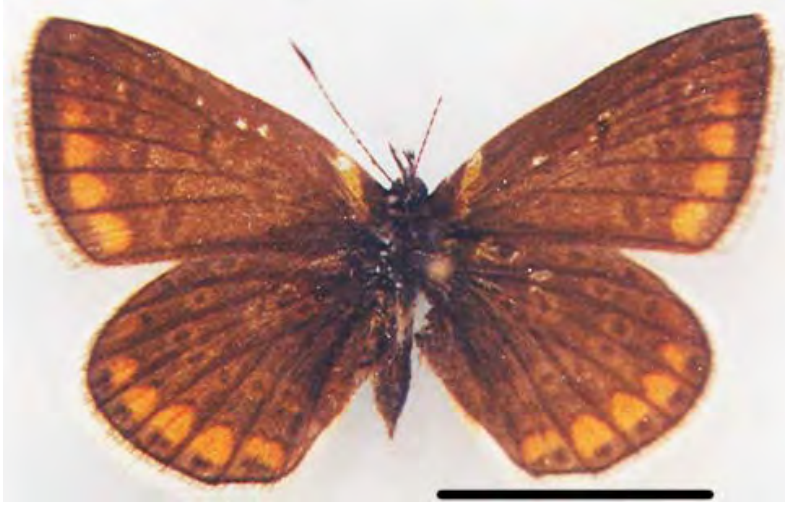

Fig. 6: Dorsal view of Polyommatus eros female

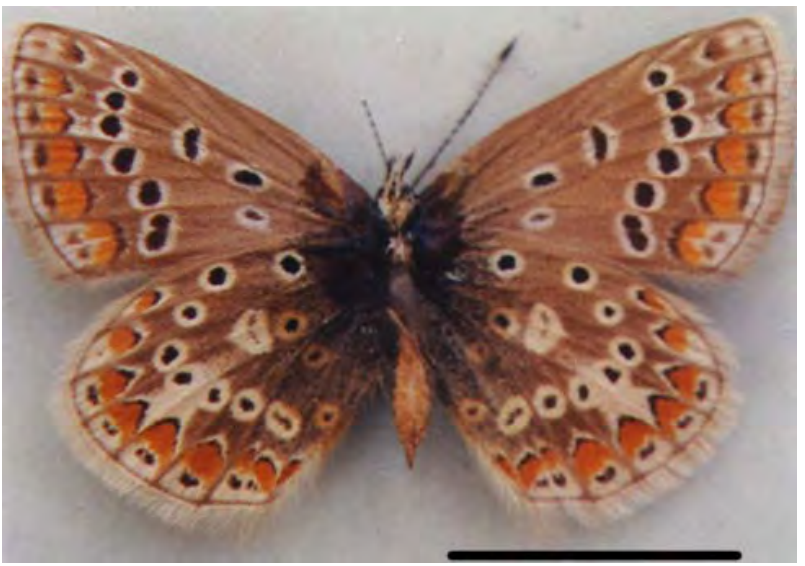

Fig. 7: Ventral view of Polyommatus eros female 
Venation: Forewings: discal cell larger than half of the wing length; veins Sc and R1 free; vein R4 wanting; vein R3 arise before middle of vein R5; base of vein M2 nearer to vein M1 than M3 at base; discocellulars incomplete. Hindwings: discal cell less than half of wing length; vein M2 equidistant between veins M1 and M3.

Male Genitalia: Uncus divided into two lobes, each lobe elongated, dorsovenrally flattened, apex broader, squarish, pilose; brachia short, slender, hook-like with sharp apices; tegument band like, suspensorium present; vinculum with upper half much broader; saccus absent; valve fusiform, costa narrow, diagonal, sacculus flap-like, from inner surface of the latter is a semi-membranous densely pilose fold; ampulla well separated from harpe, narrow, flattened; harpe broad, less sclerotized; margins and inner surface of the valve pilose; juxta U-shaped with narrow arms; aedeagus short, slender, straight, subzonal portion much larger than suprazonal portion; bulbus ejaculatorius cephalad.

Female Genitalia: Lodix squarish, upper angles rounded, lower pointed, produced outwards; genital plate membranous with inverted U-shaped strip of scleotization and a median patch of sclerotization just above ostium pouch; ductus seminalis attached to base of ductus bursae; latter slender, opens into long, elongated, membranous ostium pouch, the tip of which well sclerotized; corpus bursae oblong; apophysis anterioris long, knob-like with apex rounded; apophysis posterioris narrow, moderate in length; papilla analis subtriangular, pilose.

Forewing length: Male, 15.5-18.5 mm; Female, $15.5 \mathrm{~mm}$

Material examined: Himachal Pradesh: 2 males (14.VII, 1992), Kharapani - Lahaul Spiti (2850 m a.s.l.); 7 males (16.VII.1992), Trilokinath - Lahaul \& Spiti (3000 m a.s.l.); 1 male (20.VII.1992), Kellar - Pangi (2900 m a.s.l.); 1 male (24.VI.1995), 1 female (27.VI.1996), Puh - Kinnaur (2837 m a.s.l.); 3 males, 1 female (16.VI.1996), Rakcham Kinnaur (2900 m a.s.l.); 1 female (25.VI.1995), Hurling - Lahaul \& Spiti (2885 m a.s.l.); 1 male (26.VI.1995), Losar - Lahaul \& Spiti (4079 m a.s.l.); 3 males (20.VI.1996), Ki - Lahaul \& Spiti (4116 m a.s.l.); 8 males, 1 female (21.VI.1996), Gulling - Lahaul \& Spiti (3500 m a.s.l.); 1 male (21.VI.1996), Kaza - Lahaul \& Spiti (3600 m a.s.l.); 1 male (24.VII.2009), Sural - Pangi (3234 m a.s.l.).

Current distribution: 2837-4116 m a.s.l.
Previous distribution: Chitral-Gilgit, Baluchistan (1800-2400 m a.s.l.), Waziristan, Ladak, Kashmir (1500 m a.s.l.), Kangra, Kullu (above $2400 \mathrm{~m}$ a.s.l.), North Kumaon (3300 m a.s.l.), Sikkim, Nepal.

\section{Larval food plant: Unknown.}

Remarks: Based on the material examined, Polyommatus eros (Ochsenheimer) appears to be a very common species. Cantlie (1963) has reported as many as twelve subspecies: bilucha Moore,1884, shingara Evans,1932, wazira Evans,1932, drunela Swinhoe,1910 darshana Swinhoe,1925, janetae Evans,1927 hunza Grum - Grshimailo,1890, stoliczkana Felder \& Felder, 1865, pseuderos Moore,1879, ariana Moore, 1865, dux Riley, 1926 and arene Fawcett, 1904. Due to an overlapping range in some of these subspecies, it is likely many subspecies designations are not valid. Moreover, the reporting of this taxon from all the above mentioned localities in the North-West Himalaya represents the first distribution records for that region. While undertaking field work in one of the toughest terrains in the snow desert area of Kaza, it has been observed that the flowers of Trigonella sp. are preferred as nectar source by the adults.

Polyommatus icarus (Rottemburg, 1775) (Figs. 8-10) Common name: The Violet Meadow Blue

Rottemburg, 1775, Neturforscher 6: 21 (Papilio); Bingham, 1907, Fauna of British India, Butterflies II: 339 (Lycaena); Cantlie, 1963,Lycaenidae portion of Butterflies (Revised) : 59 (Polyommatus).

Papilio pampholyge Bergstrasser, 1779, Nomenclator und Beschreibung der Insecten, 2: pl. 47.

Papilio candybus Bergstrasser 1779, Nomenclator und Beschreibung der Insecten, 2: pl. 48, f 1, 2.

Papilio candiope Bergstrasser, 1779, Nomenclator und Beschreibung der Insecten, 2: pl. 48, f. 3, 4.

Papilio candaon Bergstrasser, 1779, Nomenclator und Beschreibung der Insecten, 3: pl. 49.

Papilio polyphemus Esper, 1780, Die (Europaischen) Schmetterlinge, 1 (2): pl. 50, 79.

Papilio fusciolus Fourcroy, 1785, Entomologia parisiensis, 2: 245.

Papilio icarinus Scriba, 1791, Journal fur die Liebhaber der Entomologie, 3: 216.

Polyommatus labienus Jermynus, 1827, The Butterfly collectors Vademecus, Ipswich, Longman: 58. Polyommatus lacon Jermynus, 1827, The Butterfly collectors Vademecus, Ipswich, Longman: 58. Polyommatus thestylis Jermynus, 1827, The Butterfly collectors Vademecus, Ipswich, Longman: 58.

Polyommatus iphis Meigen, 1830, Systematische Beschreibung der Europaischen Schmetterlinge 2 (1): 25. 
Lycaena alexis Herrich-Schäffer, [1844], Systematische Bearbeitung der Schmetterlinge von Europa, 1: pl. 52. Lycaena pusillus Gerchard, 1853, Versuch eliner Monographie der europaeischen Schmetterlingsarten, pl. 28.

Polyommatus caerulea Fuchs, 1877, Stettiner entologische Zeitung, 38 (4-6): 133.

Lycaena celina Austaut, 1879, Petites Nouvelles Entomologiques, 2 (212): 293.

Lycaena casanensis Krulikovskii, 1890, Bulletin de la Societe Imperiale des Naturalistes de Moscou (ns) 4: 223.

Lycaena rufina Oberthür, 1894, Etudes dEntomologie Etudes d'Entomologie 19: 14.

Lycaena septentrionalis Fuchs, 1901, Jahrbucher des nassauischen Vereinus fur Naturkunde Jahrbucher des nassauischen Vereinus fur Naturkunde, 53: 31.

Polyommatus semipersica Tutt, 1907, Natural History of British Butterflies 2: 175.

Lycaena taurica Venzmer, 1920, Deutsche entomologische Zeitschrift Deutsche entomologische Zeitschrift (Iris) 34: 49.

Lycaena andreas Dannehl, 1925, Entomogische Zeitschrift, 39: 76.

Lycaena analijuncta Beuret, 1926, Entomogische Zeitschrift 5 (3): 4.

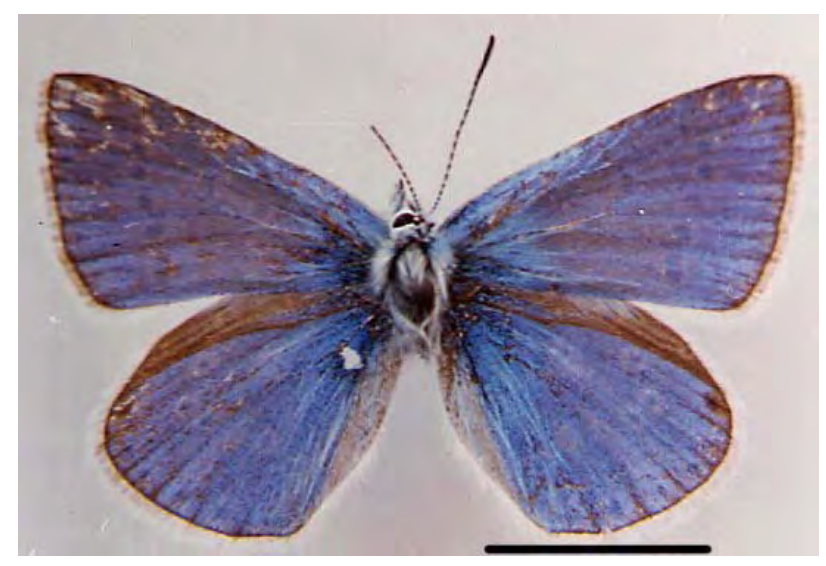

Fig. 8: Dorsal view of Polyommatus icarus male

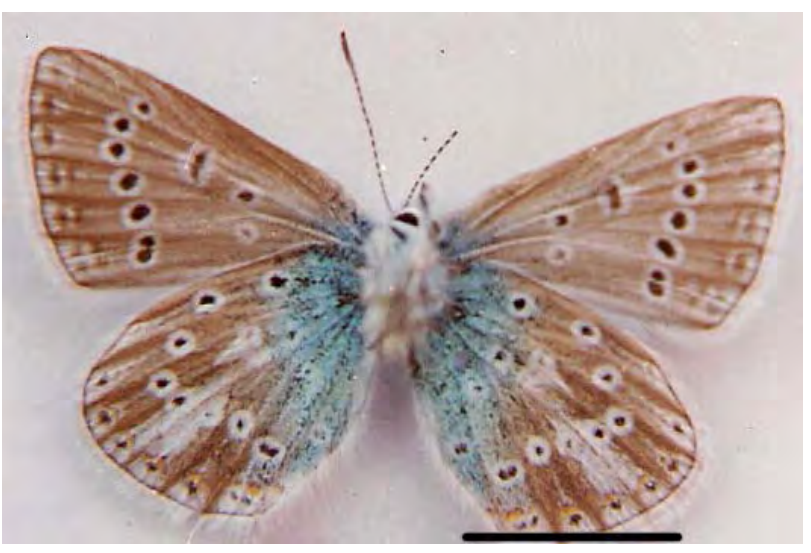

Fig. 9: Ventral view of Polyommatus icarus male

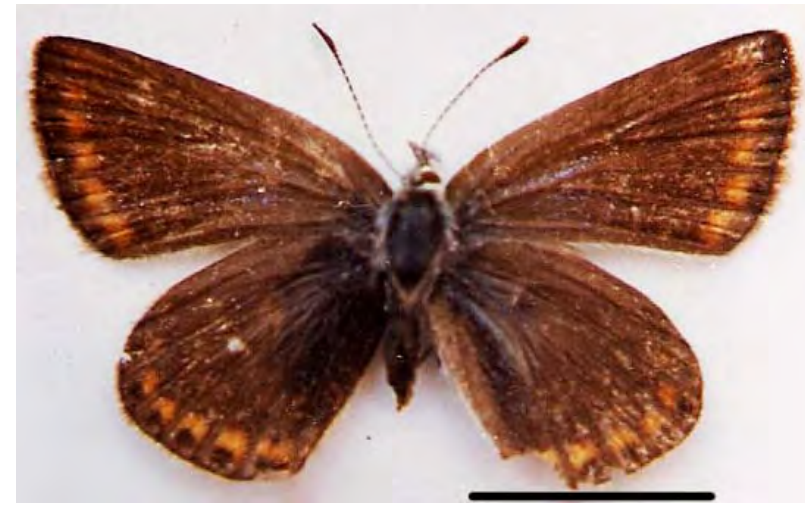

Fig. 10: Dorsal view of Polyommatus icarus female

Venation: Forewings: discal cell larger than half of the wing length; veins Sc and R1 free, briefly approximating; stalk of veins R3+R5 and vein M1 widely separated at origin; vein R4 wanting; origin of vein R3 before middle of vein R5; vein M2 closer to vein M1 than vein M3; discocellulars complete; vein $\mathrm{Cu}$-la from well before end of the cell. Hindwings: discal cell less than half of the wing length; vein M2 equidistant between vein M1 and vein $\mathrm{M} 3$; discocellulars complete; vein $\mathrm{Cu}-\mathrm{la}$ arising before end of the cell.

Male Genitalia: Symmetrical, well sclerotized, large sized; uncus divided into two lobes, each lobe narrow at base, broader posteriorly, with apex acute, sparsely pilose; brachia short, with broad bases, and evenly tapering arms with apices acute; tegumen rectangular, band-shaped, with laterally produced posterior angles; suspensorium present; vinculum with upper portion much broader, gradually tapering in lower portion; saccus absent; valva large, fusiform, costa narrow and ridge-like; sacculus elongated band-shaped, with an inner semimembranous lobe, the latter densely pilose; ampulla narrow, flat, apically curved; harpe broad, less sclerotized, lobe-shaped; lower edge of each valva straight, inner surface and margins pilose; juxta U-shaped, with gradually tapering narrow arms; aedeagus short, narrow, slender with subzone much longer than suprazone, subzone broader with laterally produced anterior end; bulbus ejaculatorius membranous, bulb-shaped; ductus ejaculatorius enters cephalad.

Female genitalia: Lodix almost squarish with upper ends rounded, lower pointed, produced; genital plate membranous, with w-shaped ribbon of sclerotization, two eye-shaped median patches on either side of ductus bursae and a central patch above ostium pouch; ductus seminalis entering near base of ductus bursae; the latter slender, opens into 
membranous; elongated ostium pouch with cresentshaped sclerotization at apex; corpus bursae oval; apophysis anterioris longer, apex rounded; apophysis posterioris moderate; papilla analis subtriangular, pilose.

Forewing length: Male, 19 mm; Female: 17-17.5 $\mathrm{mm}$.

Material examined: Himachal Pradesh: 4 females (16.VI.1993), Bharmour - Chamba (2950 m a.s.l.); 1 male, 2 females (19.VI.1995), Nako - Kinnaur (3800 m a.s.l.); 1 male (25.VI.1995), Kalpa Kinnaur (2960 m a.s.l.); 1 female (25.VI.1995), Puh - Kinnaur (2837 m a.s.l.); 2 males, 3 females (16.VI.1996), Rakcham - Kinnaur (2900 m a.s.l.); 1 male (25.VI.1995), Kaza - Lahaul \& Spiti (3600 m a.s.l.), 2 males (21.VI.1996), Gulling - Lahaul \& Spiti (3500 m a.s.l.); 1 male (23.VI.1996), Hurling Lahaul \& Spiti (2885 m a.s.l.); 1 male (24.VII.2009), 1 male (25.VII.2009), Sural - Pangi (3234 m a.s.l.).

Current distribution: 2885-3800 m a.s.l.

Previous distribution: North-West Himalaya, Baluchistan, Chitral to Muree (2700 m a.s.l.).

Larval food plant: Ononis spinosa Linn. (Papilionaceae) (Sevastopulo, 1973).

Remarks: Upon an examination of various individuals of a phenon comprising fourteen individuals (eight males and six females), it has been observed that Polyommatus icarus (Rottemburg, 1775) shows certain variations in wing maculation. For instance, the number of basal spots on undersurface of the hindwings may be either two (one male example) or three (one male example) or four (twelve examples). Also, the first discal spot in Sc+R1 may be absent (two males) or present (twelve examples) in the respective number of individuals. In order to confirm the identity of these variable specimens, a series of four males was dissected and their genitalia found to be similar, hence conspecific. Workers like Evans (1932), Peile (1937), Wynter-Blyth (1957) and Cantlie (1963) have reported the species from Baluchistan, Chitral and Muree. Hence, reporting from the present localities i.e., Bharmour Rakcham, Hurling, Gulling, Kalpa, Nako, Kaza and Puh (Himachal Pradesh) represent the first distribution records in the North-West Himalaya. An illustrated account of the male genitalia is presented to provide more detail regarding this type-species.

\section{Literature cited}

Bridges, C. A., 1988. Catalogue of Lycaenidae \& Riodinidae (Lepidoptera: Rhopalocera). Urbana, Illinois, U.S.A.

Cantlie, K., 1963. The Lycaenidae portion (except the Arhopala group) of Brigadier Evans' The Identification of Indian Butterflies 1932 (India, Pakistan, Ceylon, Burma). Bombay Natural History Society, Bombay: vi+156.

Eliot, J. N., 1973. The Higher Classification of the Lycaenidae (Lepidoptera): A Tentative Arrangement. Bulletin of the British Museum Natural History (Entomology), 28 (6):371-505.

Evans, W. H., 1932. The identification of Indian butterflies. (revised $2^{\text {nd }}$ edition). Bombay Natural History Society: $\mathrm{x}+454+32$ pls.

Hemming, A. F., 1933. Holarctic butterflies: Miscellaneous notes on nomenclature. Entomologist, $66: 275-279$.

Hemming, A. F., 1967. The Generic names of the butterflies and their type-species (Lepidoptera: Rhopalocera). Bulletin of the British Museum Natural History (Entomology), Supplement: 509.

Peile, H. D., 1937. A guide to collecting butterflies of India. Staples Press London: 523+72 pls.

Sevastopulo, D. G., 1973. The food-plants of Indian Rhopalocera. Journal of Bombay Natural History Society, 70 (1): 156-187.

Smith, C., 1989. Illustrated checklist of Nepal's butterflies. Craftsmen Press, Bangkok: 127.

Stempffer, H., 1937. Contribution a l'etude des Lycaenides de 1' Afrique orientale. Revue Francaise de Lepidopterologie, 3: 134-142.

Tutt, W. H., 1909. Natural History of British Lepidoptera, Volumes (1905-1914), 3 (6): 410+53 pls.

Tytler, H. C., 1926. Notes on some new and interesting butterflies from India and Burma. Journal of Bombay Natural History Society, 31: 248-260+1 pl.

Varshney, R. K., 1997. Index Rhoplocera Indica Pt III. Genera of Butterflies from India and neighbouring countries [Lepidoptera(C) Lycaenidae]. Oriental Insects, 31: 83-138.

Wynter-Blyth, M. A., 1957. Butterflies of the Indian Region. Bombay Natural History Soceity, Bombay: $\mathrm{xx}+523+72$ pls. 

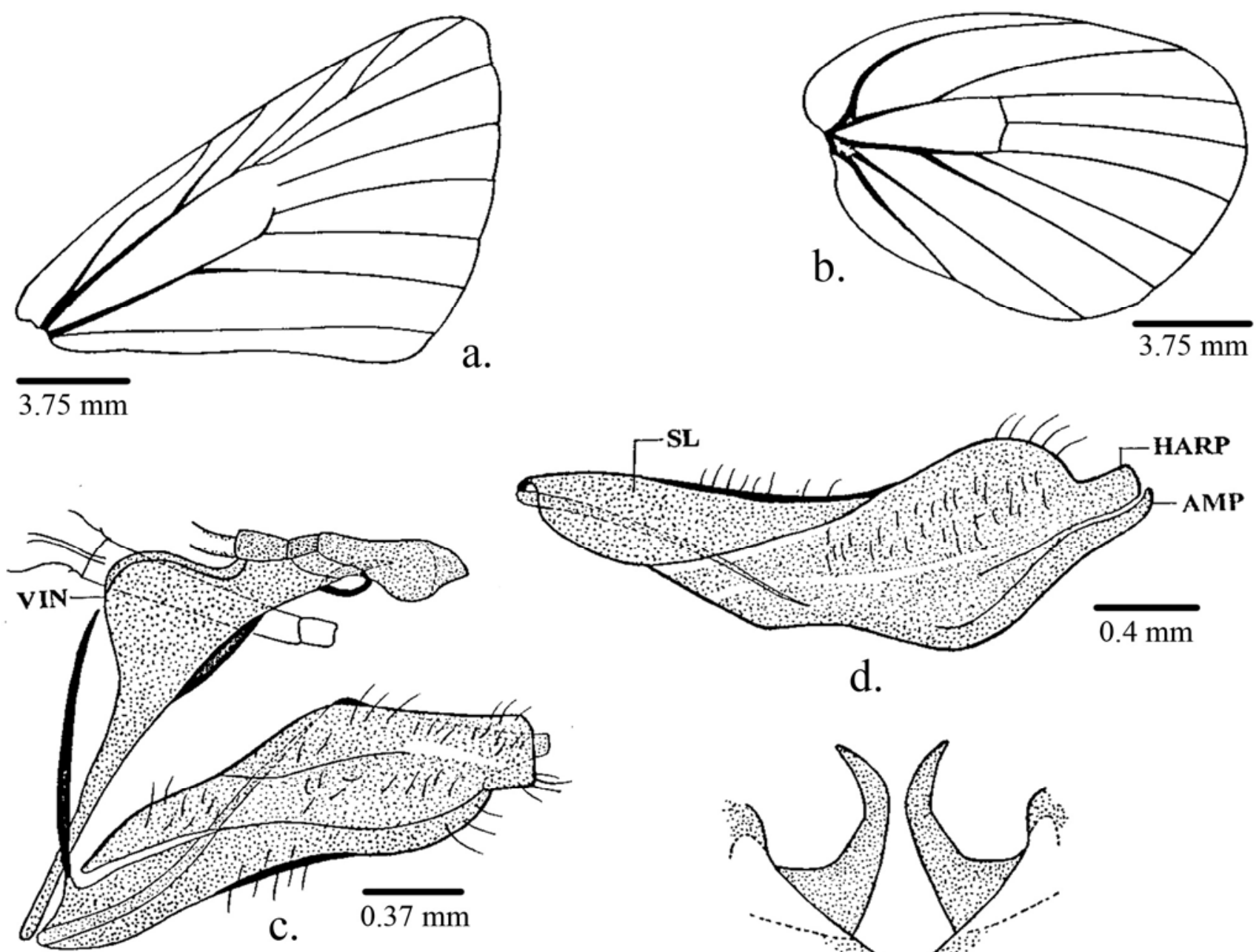

d.

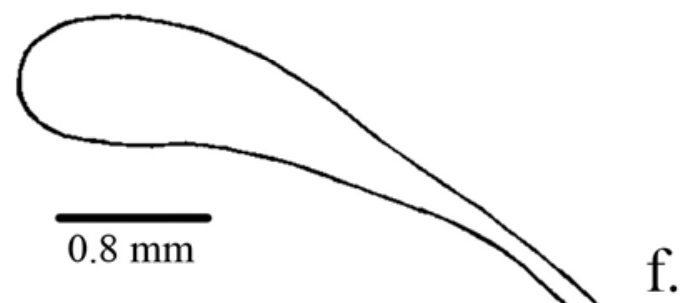

e.
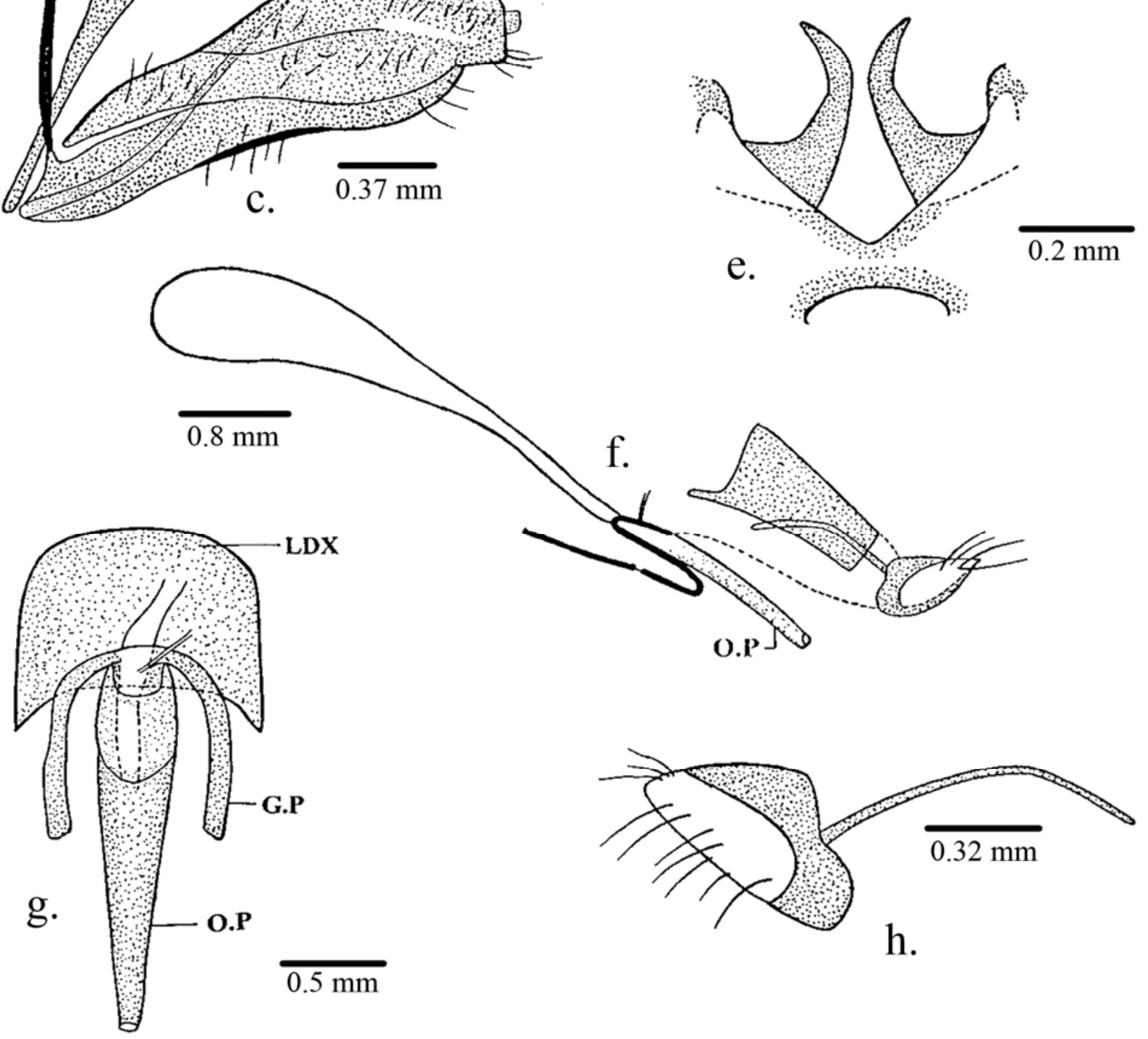

o.p
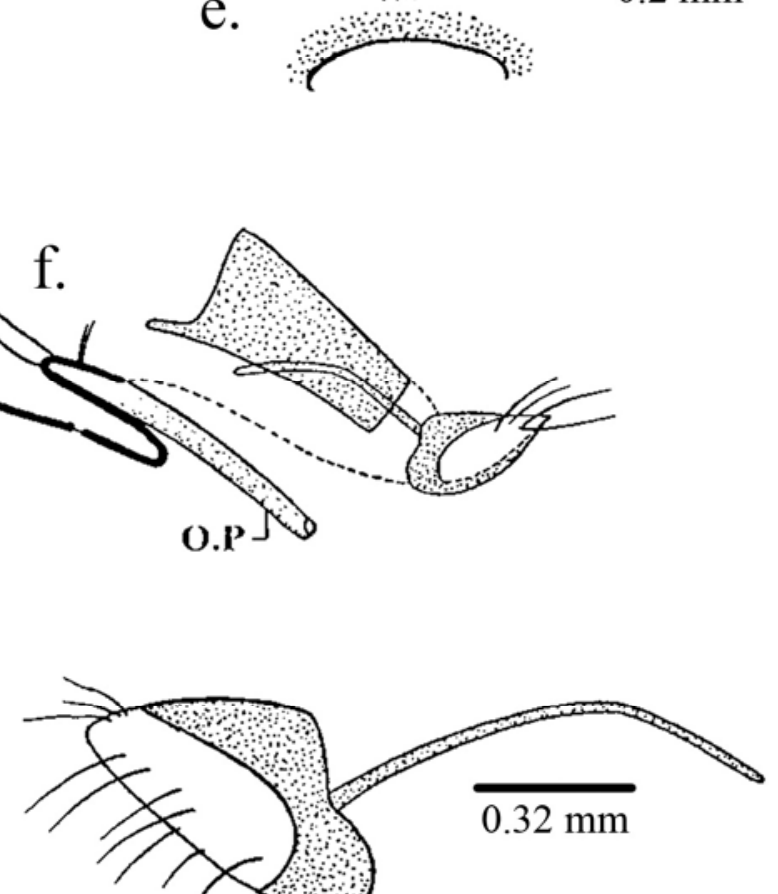

Fig. 11: Polyommatus florenciae a. venation of forewing, b. venation of hindwing, c. ale genitalia (lateral view), d. left valva (inner view), e. brachia (dorsal view), f. female genitalia (lateral view), g. genital plate, h. papilla analis 


\section{PLATE 05}

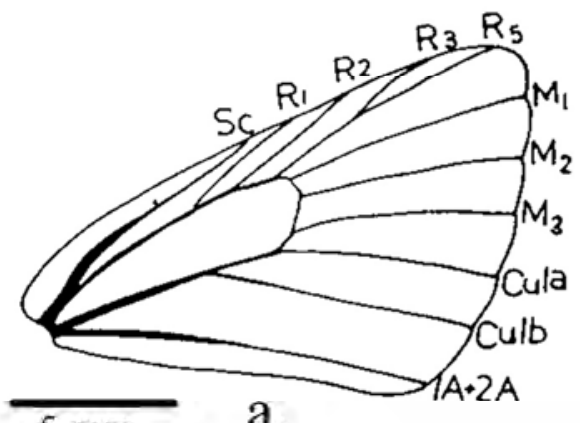

$5 \mathrm{~mm} \quad \mathrm{a}$.
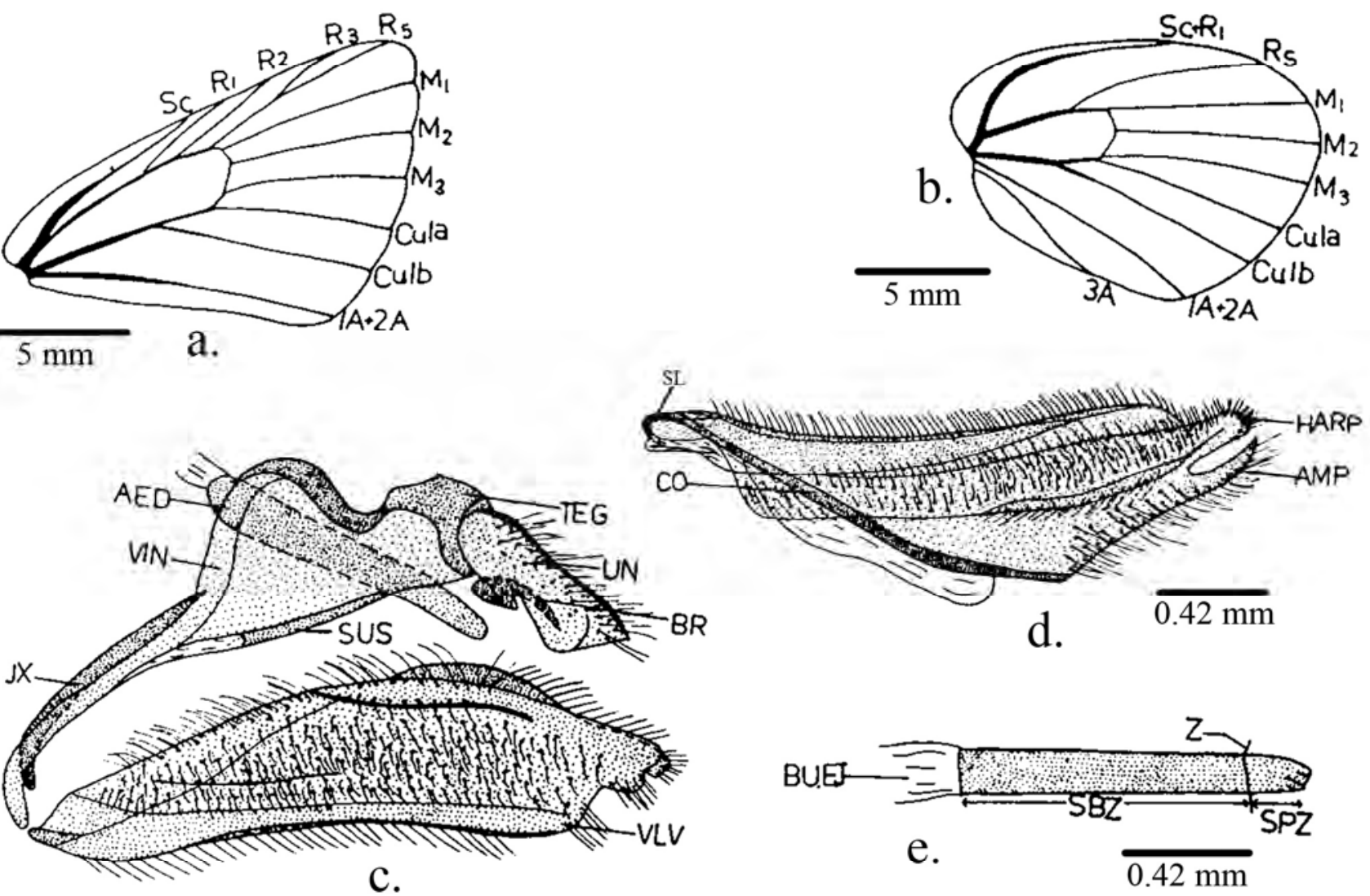

$\overline{0.42 \mathrm{~mm}}$
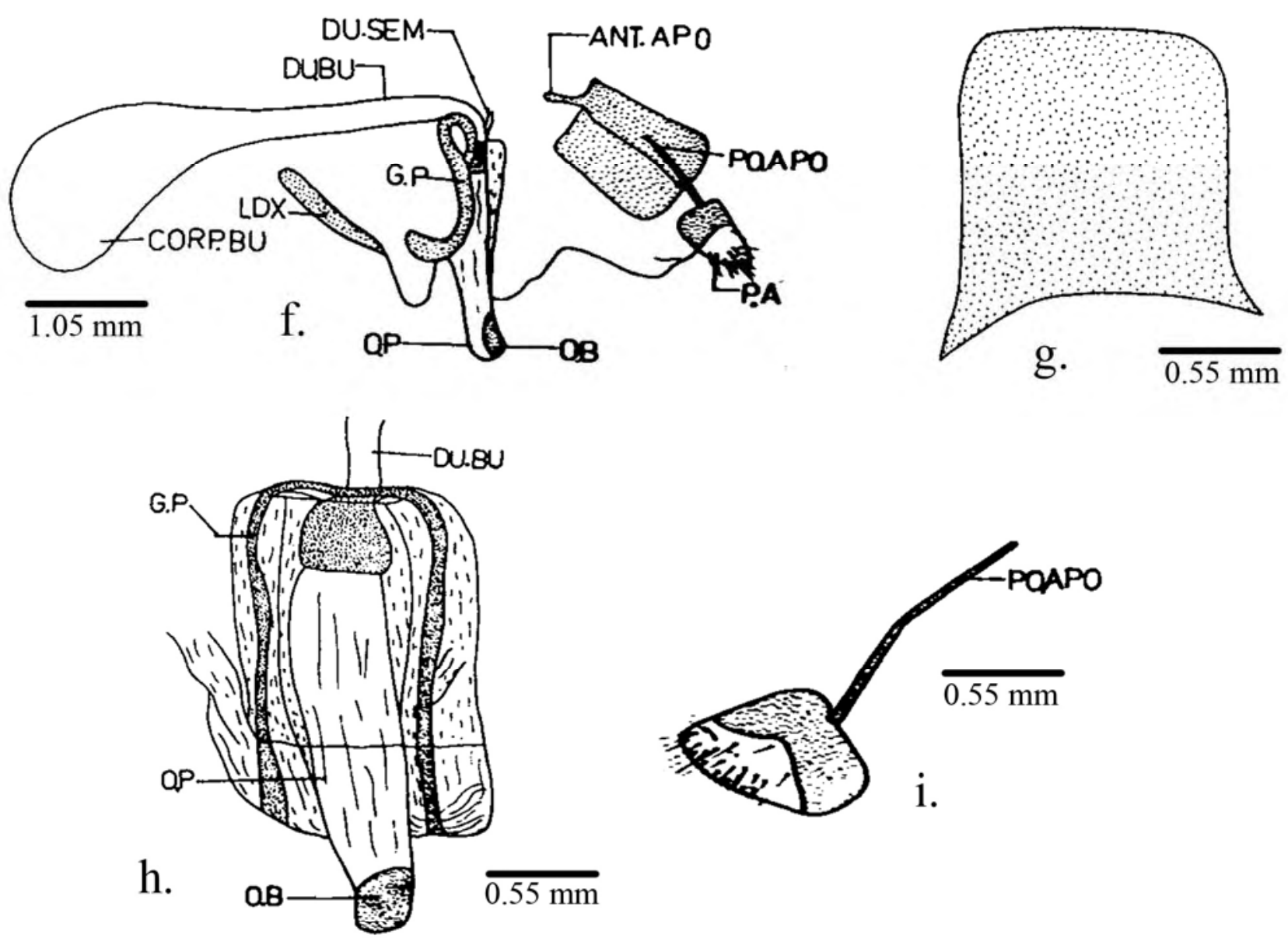

fig. 12: Polyommatus eros a. venation of forewing, b.venation of hindwing, c. male genitalia (lateral view), d. left valva (inner view), e. aedeagus (dorsal view), f. female genitalia (lateral view), g. lodix, h. genital plate, i. papilla analis 


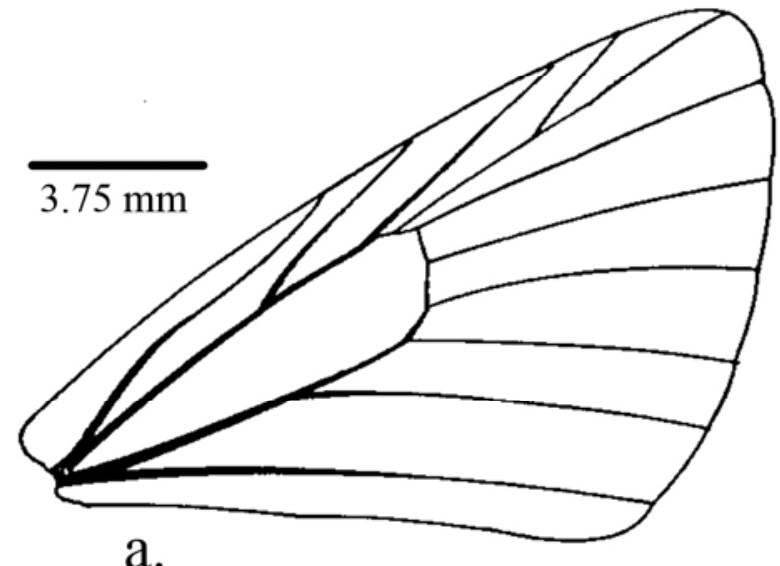

a.
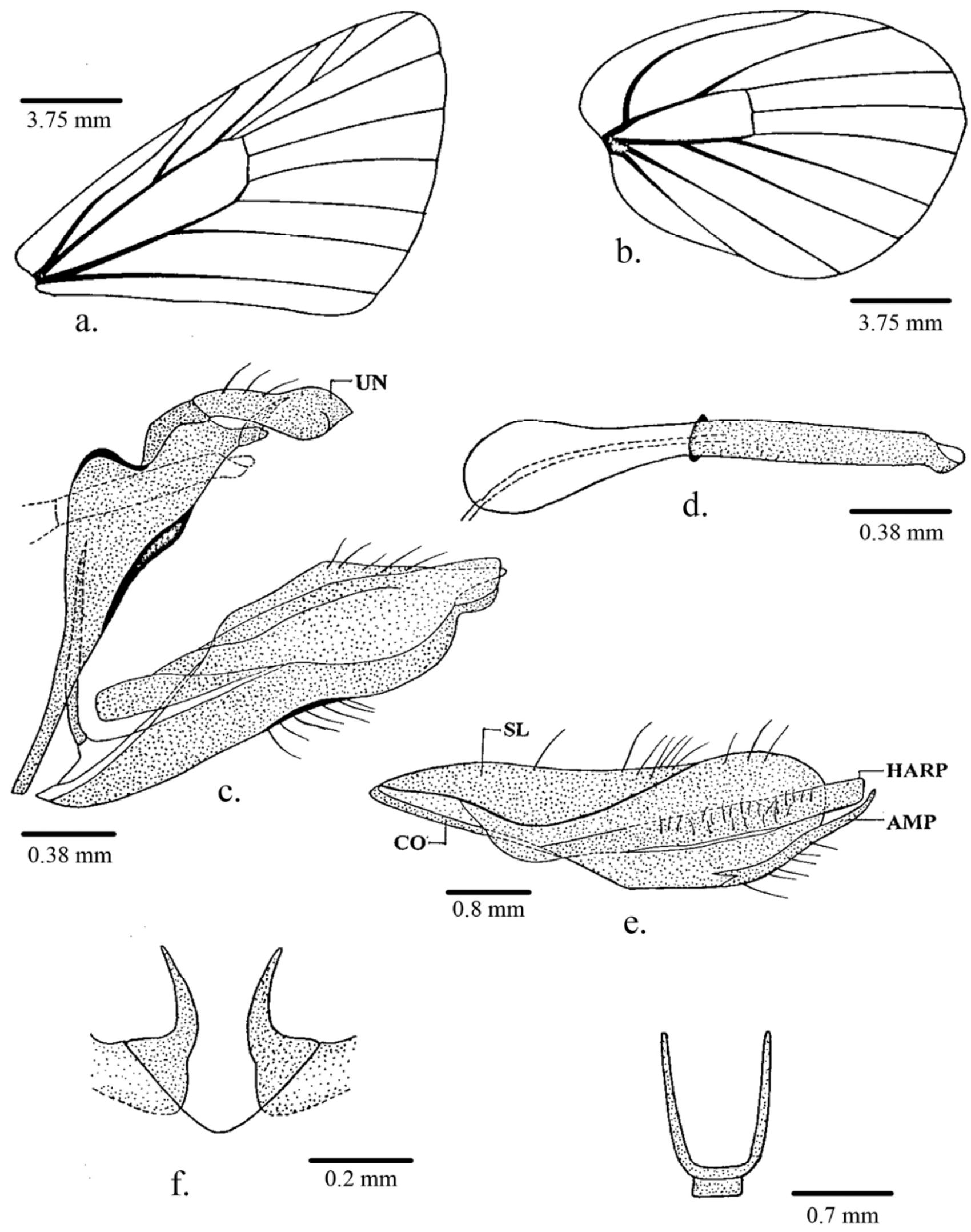

g.

fig. 13: Polyommatus icarus male a. venation of forewing, b. venation of hindwing, c. male genitalia (lateral view), d. aedeagus (lateral view), e. left valva (inner view), f. brachia (dorsal view), g. juxta 

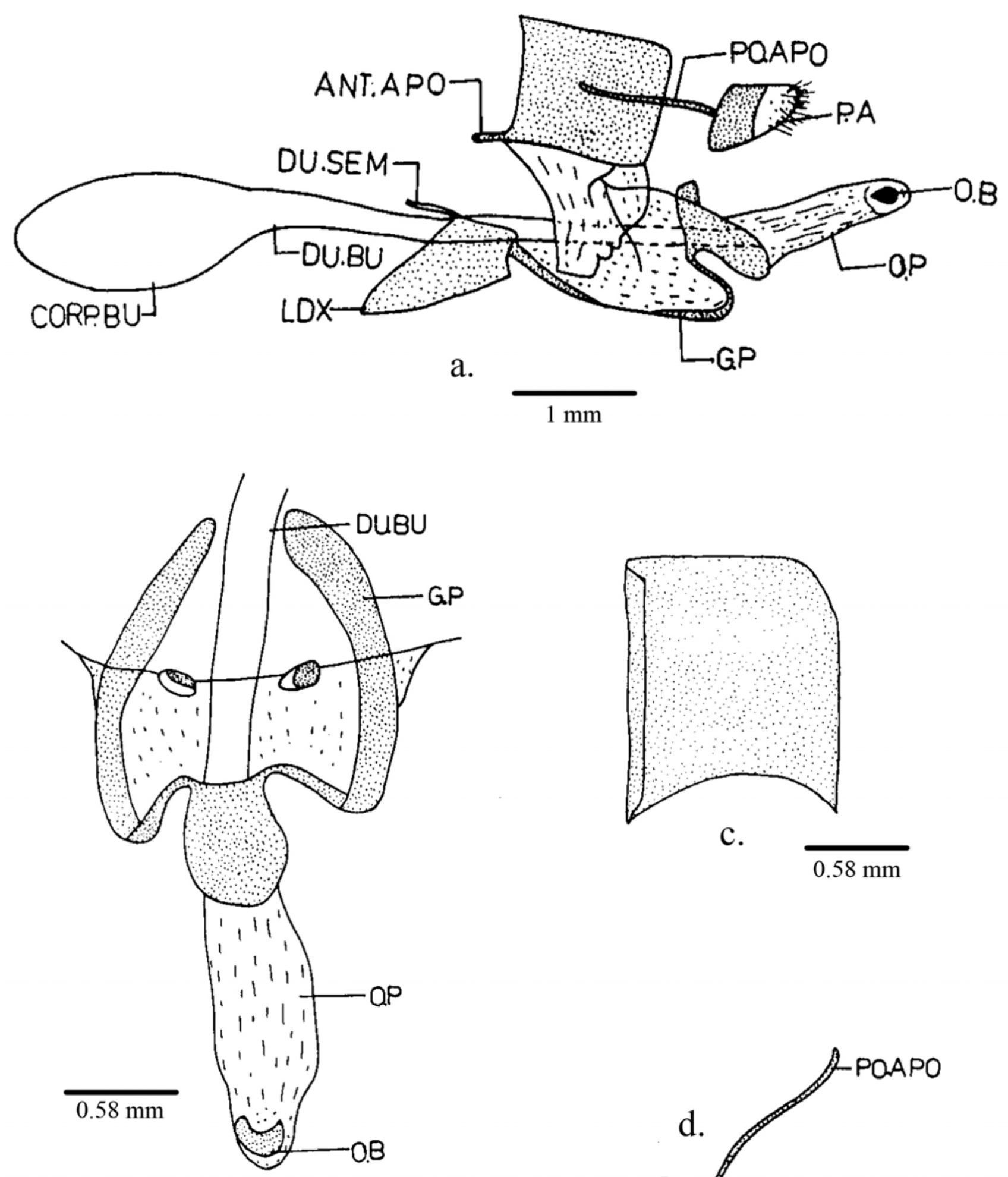

b.
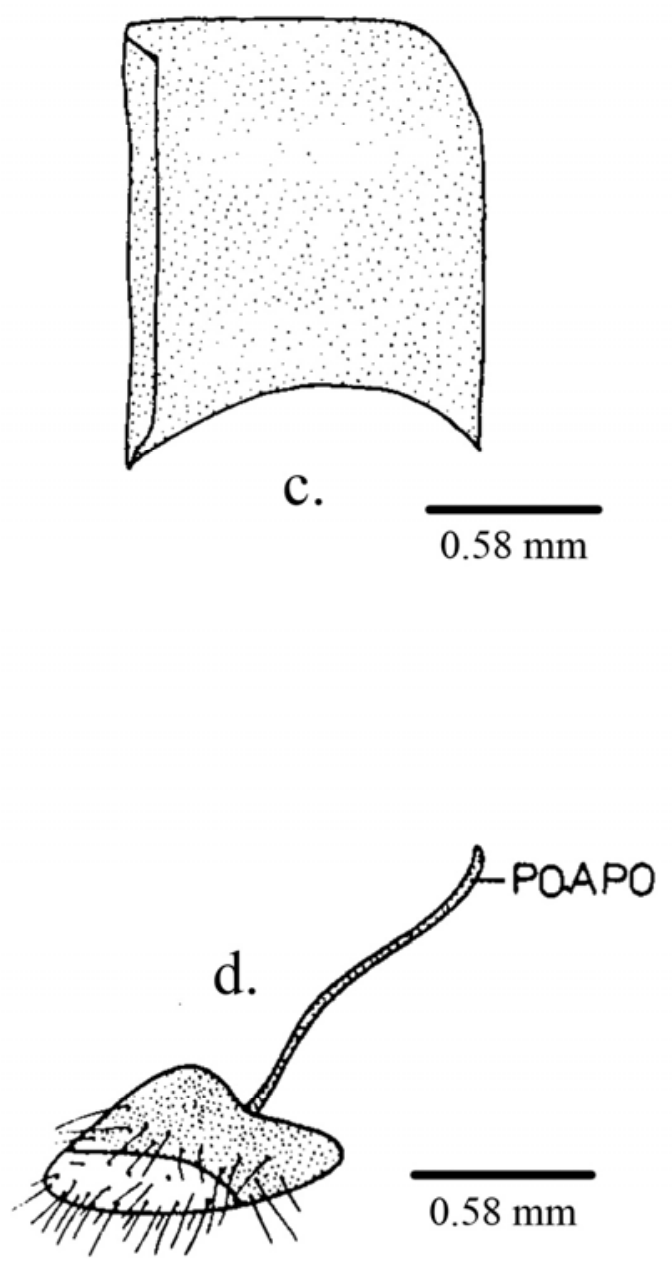

fig. 14: Polyommatus icarus female a. female genitalia (lateral View), b. genital plate, c. lodix, d. papilla analis 